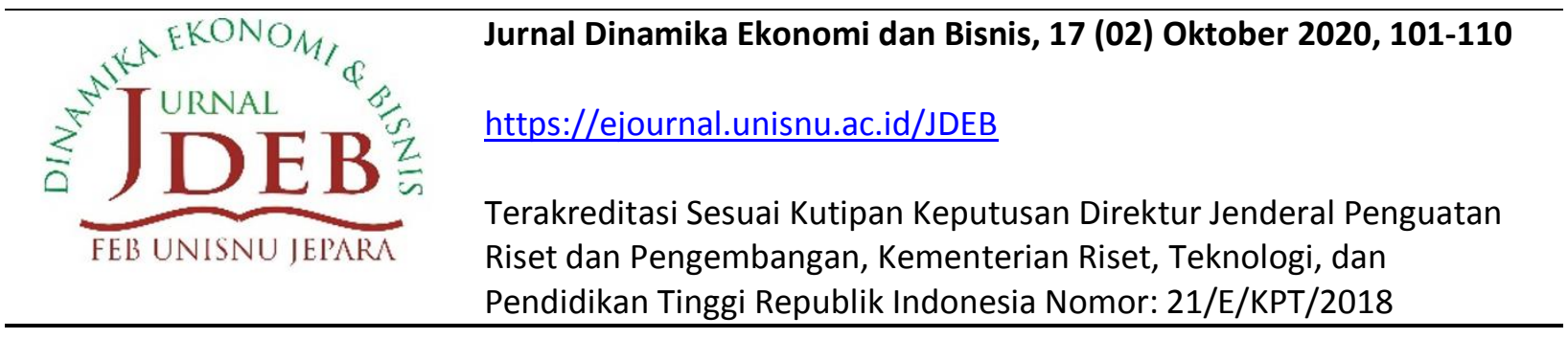

\title{
PENGARUH ROA, ROE DAN NIM TERHADAP RETURN SAHAM BANK BUMN
}

\author{
Aam Abdul Salam ${ }^{1}{ }_{*}$, Vivin Rahmawati $^{2)}$, Widya Marviani $^{3)}$, Iskandar Ahmaddien $^{4)}$ \\ Fakultas Ekonomi, Universitas Sangga Buana ${ }^{1,2,3,4)}$ \\ aambdlslm@gmail.com ${ }^{1)}$, vivinrahmawati03@gmail.com ${ }^{2)}$ widyamrvn8@gmail.com ${ }^{3)}$, \\ iskandar.ahmaddien@usbypkp.ac.id ${ }^{4)}$
}

\begin{abstract}
From this research aims to find out return on assets, return on equity and net interest margin that affect simultaneously or in part against the share price on the Indonesia Stock Exchange. This research is a comparative causal data source used from bank annual reports 2015 to 2019 from the Indonesia Stock Exchange. According to the criteria in this study, the sample is 4 i.e. state-owned banks. To analyze models and test research hypotheses, we used several statistical methods of linear regression analysis. Based on the results of hypothetical research and tests, we can conclude as follows: 1) ROA, ROE and NIM have a significant effect on stock returns; 2) ROA and ROE ratios, partially affecting stock returns, while NIM ratios have been shown to have no affect.
\end{abstract}

Keywords : Return On Assets (ROA), Return On Equity (ROE), Net Interest Margin (NIM), return shares.

\begin{abstract}
Abstrak
Dari penelitian ini bertujuan untuk mengetahui Return On Assets, Return On Equity dan Net Interest Margin yang mempengaruhi secara bersamaan atau sebagian terhadap harga saham di Bursa Efek Indonesia. Penelitian ini merupakan komparatif kausal sumber data yang digunakan dari laporan annual bank 2015 sampai 2019 dari Bursa Efek Indonesia. Menurut kriteria dalam penelitian ini, sampel adalah 4 yaitu Bank BUMN. Untuk menganalisis model dan menguji hipotesis penelitian, kami menggunakan beberapa metode statistik analisis regresi linier. Berdasarkan hasil penelitian dan tes hipotesis, kita dapat menyimpulkan sebagai berikut: 1) ROA, ROE dan NIM berpengaruh secara simultan terhadap return saham; 2) Rasio ROA dan ROE, sebagian mempengaruhi return saham, sementara rasio NIM telah terbukti tidak mempengaruhi.
\end{abstract}

Kata kunci : Return On Assets (ROA), Return On Equity (ROE), Net Interest Margin (NIM), return saham.

Sitasi: Salam, A.A, dkk (2020). Pengaruh ROA, ROE dan NIM Terhadap Return Saham Bank BUMN. Jurnal Dinamika Ekonomi dan Bisnis, 17 (02) 2020, 101-110. 


\section{PENDAHULUAN}

Investasi merupakan sesuatu hal yang dikompensasikan saat ini dan berharap memiliki pengembalian lebih di masa yang akan mendatang. Salah satu investasi yang sedang ramai pada saat ini ialah investasi saham di pasar modal (Faculty, 2016). Pasar modal adalah tempat para investor untuk menginvestasikan dananya baik itu untuk jangka panjang maupun jangka pendek. Dalam beberapa runtut waktu beberapa saham menunjukkan aktivitas positifnya. Tak lain salah satunya ialah saham dalam sektor perbankan (Suad, 2018). Dalam memulai suatu investasi tentunya para investor akan melihat terlebih dahulu dari mulai kesehatan perusahaan tersebut dalam kurun waktu minimal lima tahun dan faktor-faktor lain yang membuat para investor berkeyakinan akan menginvestasikan dananya pada perusahaan tersebut (Dempsey, 2017). Ada beberapa cara untuk mengetahui kesehatan suatu perusahaan, salah satunya dengan memperhatikan rentabilitas suatu perusahaan dan return perusahaan tersebut, berikut merupakan return saham Bank BUMN selama kurun waktu 5 tahun. Gambar 1.1 menunjukkan return saham sektor perbankan dari tahun 2015 hingga tahun 2019 yang mengalami pergerakan fluktuatif.

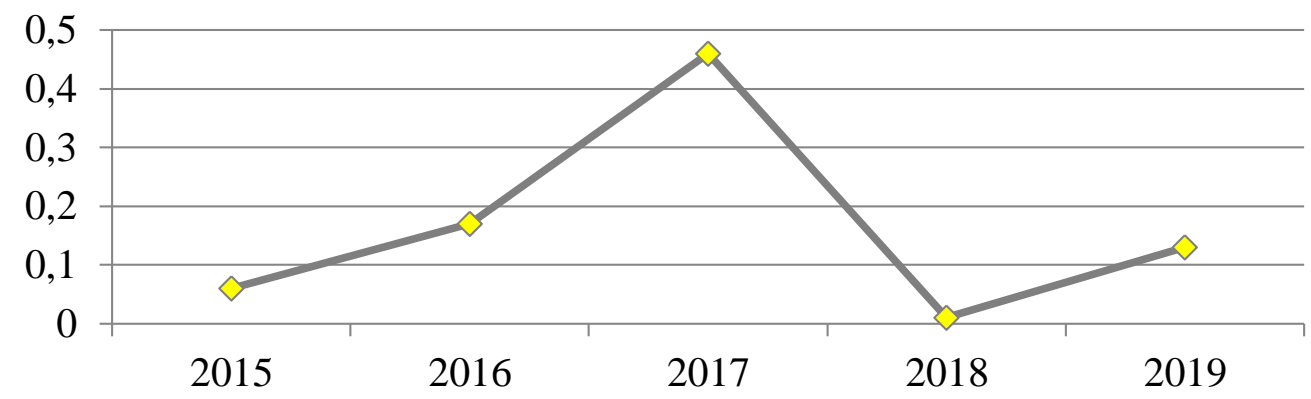

Gambar 1. Return Saham Sektor Perbankan 2015-2019

Pada Gambar 1. Return saham sektor perbankan dari tahun 2015 hingga 2019 mengalami pergerakan yang fluktuatif. Dimulai pada tahun 2015 hingga tahun 2017 return saham sektor perbankan mengalami peningkatan hingga 52\%. Namun pada tahun 2017 hingga tahun 2018, pergerakan return saham sektor perbankan sempat mengalami penurunan hingga 45\%. Walaupun begitu pada tahun 2018 hingga tahun 2019 mulai mengalami peningkatan kembali hingga 12\% Rentabilitas merupakan keahlian perusahaan dalam mencetak laba. Dalam sektor perbankan rentabilitas bisa diukur dari Return On Assets, Return On Equity, dan Net Interest Margin.

Rasio Return On Asset menggambarkan keahlian perbankan dalam mendapatkan laba atau keuntungan dari seluruh asset yang dimilikinya (Rosada, 2003). Rasio Return On Equity menggambarkan kemampuan perbankan dalam mendapatkan laba atau keuntungan dari seluruh modal yang dimilikinya (Asri, 2017). Rasio Net Interest Margin menggambarkan pemasukan dari bunga bersih yang didapatkan dari aktiva produktif (Johar, 2017)

Berdasarkan latar belakang masalah penulis akan meneliti: Rasio Return On Assets, Return On Equity, dan Net Interest Margin apa ada pengaruh simultannya ataupun parsialnya, terhadap harga saham pada PT Bursa Efek Indonesia?

Dari beberapa rumusan masalah diatas, ada tujuan yang diharapkan dalam penelitian yang diteliti ini diantaranya: 
1. Return On Assets, Return On Equity, dan Net interest margin ada pengaruh simultan dan parsial terhadap return saham pada bank yang sudah terdaftar dan tercatat di PT Bursa Efek Indonesia.

2. Return On Assets, Return On Equity, dan Net interest margin ada pengaruh secara parsial terhadap harga.

\section{Landasan Teori}

\section{Rasio Return On Asset (ROA)}

Menurut (Nyoman et al., 2010) Return On Asset ROA adalah rasio yang mengukur perbandingan antara laba sebelum pajak dengan total aktiva yang di miliki perusahaan. Semakin tinggi tingkat ROA menunjukan kinerja keuangan semakin baik, karena return yang dihasilkan semakin besar.

Semakin meningkat rasio ROA akan semakin meningkat juga tingkat pemulangan terhadap investor, dengan melihat rasio ROA yang baik, maka investor akan lebih tertarik untuk menginvestasikan dananya pada perusahaan tersebut (Parenrengi \& Hendratni, 2018)

\section{Rasio Return On Equity (ROE)}

Menurut (Sartono, 2012:124), Pengertian ROE adalah rasio untuk mengukur kemampuan perusahaan untuk mendapatkan laba yang tersedia bagi pemegang saham. Return On Equity dapat mencerminkan keuntungan perusahaan berdasarkan modal dari saham tertentu yang dimana menjadikan tolok ukur bagi para investor (Johar, 2017)

\section{Rasio Net Interest Margin (NIM)}

Menurut (Taswan, 2016) "Perbandingan antara rata-rata aktiva produktif terhadap pendapatan bunga bersih. Rasio ini menunjukkan kemampuan bank dengan cara menghasilkan pendapatan bunga bersih dengan menempatan aktiva produktif. (Saputri, 2018) Semakin besar rasio NIM maka akan semakin baik kinerja suatu bank dalam menghasilkan pendapatan bunga. Dan harus dipastikan bahwa ini bukan hanya karena biaya intermediasi yang tinggi, asumsinya tetap pendapatan bunga yang harus ditanamkan demi memperkuat modal bank."

Net Interest Margin adalah rasio yang digunakan untuk mengukur rentabilitas pada dunia perbankan. Jika NIM ini semakin tinggi makan pendapatan bunga bersihnyapun akan semakin tinggi pula. Jika sebaliknya rasio NIM ini rendah makan rendah pula pendapatan bunga bersih bagi perusahaan(Syariah, n.d.)

\section{Return Saham}

Menurut (Jogiyanto Hartono, 2003) Jenis saham ada dua, yang pertama return realisasi dan yang kedua return ekspektasi. Return realisasi adalah pemulangan hasil investasi yang telah terjadi dan return ekspektasi adalah pemulangan hasil investasi yang di angan - angan di kemudian hari. Return saham adalah buah perolehan dari investasi yang di hitung dengan cara mengkalkulasikan perbedaan harga saham waktu berjalan dengan waktu sebelum dengan cara melepaskan deviden 


\section{Penelitian Terdahulu}

(Chairatanawan, 2008) meneliti hubungan antara beberapa rasio keuangan yang mencakup Gross Profit Margin, EBIT/Net Sales, ROE, ROA, Current Ratio, Liquid Ratio, Gearing Ratio, Debt to Equity, Interest Overage, Dividen Yields (DY), Price Earnings (PE) dan Price to Book Value (PBV) (Aldi et al., 2015)dengan tingkat pengembalian (rate of return) saham beberapa perusahaan di Bursa Efek Thailand periode Januari 1997 - Desember 2004. Hasil penelitian menyebutkan bahwa hubungan antara tingkat pengembalian (rate of return) dengan ratio keuangan tidak dapat dibuktikan.

\section{Hipotesis}

Di prediksi rasio Return On Assets, Return On Equity, dan Net interest margin berpengaruh secara simultan maupun parsial terhadap return saham pada bank BUMN yang sudah terdaftar dan tercatat di Bursa Efek Indonesia.

\section{Metode Penelitian Sample}

Dalam pengambilan sample ada ketentuan yang digunakan pada penelitian yang akan diteliti yaitu dengan menggunakan purposive sampling, Populasi yang di jadikan sample pada penelitian ini adalah sample populasi yang benar - benar memenuhi standard sample yang sudah sesuai dengan apa yang akan dibutuhkan seorang peneliti untuk penelitiannya. Sifat data nya yaitu time series atau periode tahunan dan diputuskan sample yang di ambil 5 periode mulai dari tahun 2015 sampai tahun 2019. Standard yang digunakan dalam mengambil sample diantaranya adalah:

1. Bank yang akan di ambil yaitu bank yang sudah terdaftar dan tercatat di PT Bursa Efek Indonesia pada tahun 2015 ke belakang juga yang terdaftar dan tercatat sebagai perusahaan yang melakukan penawaran secara umum sampai pada akhir tahun 2019.

2. Bank yang sudah menyebarluaskan laporan keuangan secara terus menerus selama tahun 2015 sampai tahun 2019.

3. Beberapa Bank yang tercatat dalam golongan 10 Bank yang terbesar dari segi asset yang tercatat dan terdaftar di Bursa Efek Indonesia berdasarkan standard, inilah perbankan yang sesuai standard untuk mewakili perbankan adalah sebagai berikut :
a. PT Bank Mandiri (Persero) Tbk - ( BMRI )
b. PT Bank Rakyat Indonesia (Pesero) Tbk - ( BBRI)
c. PT Bank Negara Indonesia (Pesero) Tbk - ( BBNI )
d. PT Bank Tabungan Negara Tbk - (BBTN )

\section{Teknik Analisa Data}

Model yang akan digunakan untuk mengkaji metode statistic analisis regresi berganda dengan menggunakan software komputer Eviews 9.

\section{Hasil dan Pembahasan}

Hasil penelitian yang sudah diteliti di beberapa bank yang telah terdaftar dan tercatat di PT Bursa Efek Indonesia tentang Return On Asset, Return On Equity, Net Interest Margin, dan Return Saham pada periode tahun 2015 sampai tahun 2019 didapatkan hasil sebagai 
berikut:

\section{Perkembangan Rasio ROA (Return On Asset)}

Penelitian Return On Asset pada bank yang dijadikan sample pada penelitian tahun 2015 - 2019 didapat hasilnya sebagai berikut:

Tabel 1. Rasio Return On Asset (ROA) Periode Tahun 2015 - 2019

\begin{tabular}{clllcccc}
\hline \multirow{2}{*}{ NO } & KODE & \multicolumn{7}{c}{ TAHUN } & Rata- \\
\cline { 3 - 7 } & SAHAM & $\mathbf{2 0 1 5}$ & $\mathbf{2 0 1 6}$ & $\mathbf{2 0 1 7}$ & $\mathbf{2 0 1 8}$ & $\mathbf{2 0 1 9}$ & Rata \\
\hline 1 & BBNI & 0,03 & 0,03 & 0,03 & 0,03 & 0,02 & 0,03 \\
2 & BBRI & 0,04 & 0,04 & 0,04 & 0,04 & 0,04 & 0,04 \\
3 & BBTN & 0,02 & 0,02 & 0,02 & 0,01 & 0,00 & 0,01 \\
4 & BMRI & 0,03 & 0,02 & 0,03 & 0,03 & 0,03 & 0,03 \\
\hline \multicolumn{7}{l}{ Sumber: }
\end{tabular}

Berdasarkan tabel 1 dapat dijelaskan bahwa terdapat rasio Return On Asset rata-rata dengan nilai tertinggi terdapat pada PT. Bank Rakyat Indonesia Tbk. Dengan kode saham (BBRI) yaitu diangka 0,04 dalam runtut waktu 5 tahun yaitu dari tahun 2015-2019. Lebih baik dibandingkan 3 Bank BUMN lainnya yaitu PT. Bank Negara Indonesia Tbk, PT. Bank Tabungan Negara Tbk, PT. Bank Mandiri Tbk.

\section{Perkembangan Rasio ROE (Return On Equity)}

Penelitian Return On Equity pada bank yang dijadikan sample pada penelitian tahun 2015 - 2019 didapat hasilnya pada Tabel 2 sebagai berikut:

Tabel 2. Rasio Return On Equity (ROE) Periode Tahun 2015 - 2019

\begin{tabular}{clcccccc}
\hline \multirow{2}{*}{ NO } & KODE & \multicolumn{5}{c}{ TAHUN } & $\begin{array}{c}\text { Rata- } \\
\text { Rata }\end{array}$ \\
\cline { 5 - 7 } & SAHAM & $\mathbf{2 0 1 5}$ & $\mathbf{2 0 1 6}$ & $\mathbf{2 0 1 7}$ & $\mathbf{2 0 1 8}$ & $\mathbf{2 0 1 9}$ & 0,16 \\
1 & BBNI & 0,17 & 0,16 & 0,16 & 0,16 & 0,14 & 0,16 \\
2 & BBRI & 0,30 & 0,23 & 0,20 & 0,20 & 0,19 & 0,23 \\
3 & BBTN & 0,17 & 0,18 & 0,18 & 0,15 & 0,01 & 0,14 \\
4 & BMRI & 0,23 & 0,11 & 0,15 & 0,16 & 0,15 & 0,16 \\
\hline
\end{tabular}

Sumber: Website Bursa Efek Indonesia

Berdasarkan tabel 2 dapat dijelaskan bahwa terdapat rasio Return On Equity rata-rata dengan nilai tertinggi terdapat pada PT. Bank Rakyat Indonesia Tbk. Dengan kode saham (BBRI) yaitu diangka 0,23 dalam runtut waktu 5 tahun yaitu dari tahun 2015-2019. Lebih baik dibandingkan 3 Bank BUMN lainnya yaitu PT. Bank Negara Indonesia Tbk, PT. Bank Tabungan Negara Tbk, PT. Bank Mandiri Tbk. Maka dari itu PT. Bank Rakyat Indonesia Tbk dikatakan baik dalam pembiayaan modal atas laba.

\section{Perkembangan Rasio NIM (Net Interest Margin)}

Penelitian Net Interest Margin pada bank yang dijadikan sample pada penelitian tahun 2015 - 2019 didapat hasilnya sebagai berikut: 
Tabel 3. Rasio Net Interest Margin (NIM) Periode Tahun 2015 - 2019

\begin{tabular}{clcccccc}
\hline \multirow{2}{*}{ NO } & KODE & \multicolumn{7}{c}{ TAHUN } & Rata- \\
\cline { 3 - 7 } & SAHAM & $\mathbf{2 0 1 5}$ & $\mathbf{2 0 1 6}$ & $\mathbf{2 0 1 7}$ & $\mathbf{2 0 1 8}$ & $\mathbf{2 0 1 9}$ & Rata \\
\hline 1 & BBNI & 0,06 & 0,06 & 0,06 & 0,05 & 0,05 & 0,06 \\
2 & BBRI & 0,08 & 0,08 & 0,08 & 0,07 & 0,07 & 0,08 \\
3 & BBTN & 0,05 & 0,05 & 0,05 & 0,04 & 0,03 & 0,04 \\
4 & BMRI & 0,06 & 0,06 & 0,06 & 0,06 & 0,05 & 0,06 \\
\hline
\end{tabular}

Sumber: Website Bursa Efek Indonesia

Berdasarkan tabel 3 dapat dijelaskan bahwa terdapat rasio NIM (Net Interest Margin) rata-rata dengan nilai terendah terdapat pada PT. Bank Tabungan Negara Tbk. Dengan kode saham (BBTN) yaitu diangka 0,04 dalam runtut waktu 5 tahun yaitu dari tahun 2015-2019. Lebih baik dibandingkan 3 Bank BUMN lainnya yaitu PT. Bank Negara Indonesia Tbk, PT. Bank Rakyat Indonesia Tbk, PT. Bank Mandiri Tbk. Maka dari itu PT. Bank Tabungan Negara Tbk dikatakan baik dalam mendapatkan pendapatan bunga bersih yang didapat dari aktiva produktif yang dimiliki lebih rendah dari pada bank yang lainnya.

\section{Perkembangan Return Saham}

Penelitian Return Saham pada bank yang dijadikan sample pada penelitian tahun 2015 sampai tahun 2019 didapat hasilnya sebagai berikut:

Tabel 4. Return Saham Bank BUMN Periode Tahun 2015 - 2019

\begin{tabular}{cccccccc}
\hline \multirow{2}{*}{ NO } & KODE & \multicolumn{5}{c}{ TAHUN } & Rata- \\
\cline { 3 - 7 } & SHAM & $\mathbf{2 0 1 5}$ & $\mathbf{2 0 1 6}$ & $\mathbf{2 0 1 7}$ & $\mathbf{2 0 1 8}$ & $\mathbf{2 0 1 9}$ & Rata \\
\hline 1 & BBNI & $-0,01$ & 0,01 & 0,05 & 0,00 & $-0,01$ & 0,01 \\
2 & BBRI & 0,00 & 0,01 & 0,05 & 0,00 & 0,01 & 0,02 \\
3 & BBTN & 0,03 & 0,02 & 0,04 & $-0,01$ & 0,00 & 0,02 \\
4 & BMRI & 0,03 & 0,04 & 0,06 & $-0,02$ & $-0,02$ & 0,02 \\
\hline Sumber: Website Bursa Efek Indonesia
\end{tabular}

Sumber: Website Bursa Efek Indonesia

Berdasarkan tabel 4 dapat dijelaskan bahwa terdapat return saham keempat Bank BUMN yang paling mendominasi lebih banyak pengembalian terhadap para investor ada pada PT. Bank Rakyat Indonesia Tbk, PT. Bank Rakyat Indonesia Tbk, PT. Bank Mandiri Tbk. Dengan rata-rata pengembalian di angka 0,02 dalam kurun waktu 5 tahun, yaitu dari tahun 2015-2019. Jadi, ketiga Bank tersebut dikatakan performanya baik dalam kurun waktu 5 tahun dibandingkan dengan PT. Bank Rakyat Indonesia Tbk. 
Analisis Model dan Pengujian Hipotesis.

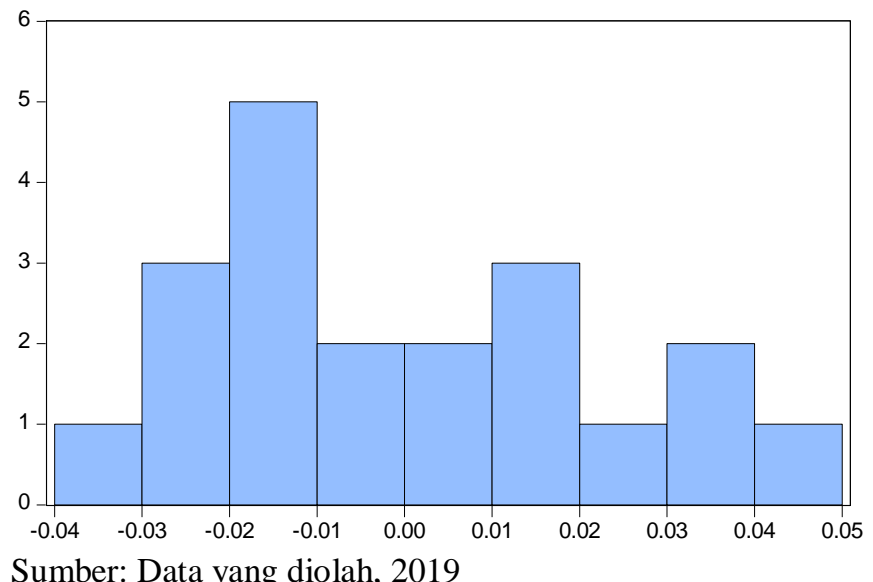

Gambar 2. Uji Normalitas

Sumber: Data yang diolah, 2019
Series: Standardized Residuals

Sample 20152019

Observations 20

Mean $\quad-1.86 \mathrm{e}-17$

Median $\quad-0.003784$

Maximum $\quad 0.045836$

Minimum $\quad-0.033535$

Std. Dev. $\quad 0.022862$

Skewness $\quad 0.442643$

Kurtosis $\quad 2.041989$

Jarque-Bera 1.417931

Probability $\quad 0.492153$

Dikatakan normal jika probability > 0,05. Maka dalam kasus ini dari keempat variabel yang telah diujikan dikatakan berdistribusi normal, karena probability $>0,05$ yaitu sebesar 0,492153 .

Tabel 5. Uji Chi Effect Model

\begin{tabular}{crrrl}
\hline Variable & Coefficient & Std. Error & t-Statistic & Prob. \\
\hline C & -0.034238 & 0.033553 & -1.020414 & 0.3227 \\
ROA & -1.451099 & 1.344198 & -1.079528 & 0.2964 \\
ROE & -0.062886 & 0.165400 & -0.380205 & 0.7088 \\
NIM & 1.689467 & 1.095775 & 1.541802 & 0.1427 \\
\hline
\end{tabular}

Sumber: Data yang diolah, 2019

Tabel 6. Uji Fixed Effect Model

\begin{tabular}{crrrl}
\hline Variable & Coefficient & Std. Error & t-Statistic & Prob. \\
\hline C & -0.149523 & 0.056634 & -2.640138 & 0.0204 \\
ROA & 0.453241 & 1.608725 & 0.281739 & 0.7826 \\
ROE & -0.292764 & 0.187307 & -1.563017 & 0.1421 \\
NIM & 3.432968 & 1.269632 & 2.703908 & 0.0181 \\
\hline
\end{tabular}

Sumber: Data yang diolah, 2019

Tabel 7. Uji Chow

\begin{tabular}{llrc}
\hline Effects Test & Statistic & d.f. & Prob. \\
\hline Cross-section F & 2.124026 & $(3,13)$ & 0.1465 \\
Cross-section Chi-square & 7.977667 & 3 & 0.0465 \\
\hline
\end{tabular}

Sumber: Data yang diolah, 2019

Dalam Uji Chow kita akan melihat Cross-section F jika > 0,05 maka model uji Chi Effect Model yang akan digunakan dan sebaliknya jika Cross-section $\mathrm{F}<0,05$ maka uji Fixed Effect Model yang digunakan. Dalam kasus ini dikarenakan Cross-section F > 0,05 uji yang dipilih ialah uji Chi Effect Model. 
Tabel 8. Uji Random Effect Model

\begin{tabular}{crrrc}
\hline Variable & Coefficient & Std. Error & t-Statistic & Prob. \\
\hline ROA & -1.451099 & 1.221617 & -1.187851 & 0.2522 \\
ROE & -0.062886 & 0.150317 & -0.418356 & 0.6812 \\
NIM & 1.689467 & 0.995848 & 1.696511 & 0.1092 \\
C & -0.034238 & 0.030493 & -1.122806 & 0.2781 \\
\hline
\end{tabular}

Sumber: Data yang diolah, 2019

Tabel 9. Uji Hausman

\begin{tabular}{|c|c|c|c|}
\hline \multicolumn{3}{|c|}{ Test cross-section random effects } & \multirow{2}{*}{ Prob. } \\
\hline Test Summary & Chi-Sq. Statistic & Chi-Sq. d.f. & \\
\hline Cross-section random & 6.372077 & 3 & 0.0948 \\
\hline
\end{tabular}

Jika tadi dalam uji chow model pengujian Chi Effect Model yang dipilih maka dalam uji hausman ini kita akan bandingkan lagi dengan model uji Random Effect Model. Jika Cross-section random model > 0,05 maka uji yang dipakai adalah Random Effect Model, namun sebaliknya jika Cross-section random model < 0,05 makan uji Chi Effect Model yang akan dipakai. Namun, dalam kasus ini telah didapat hasil uji dimana Cross-section random model > 0,05 dengan ini maka uji Random Effect Model yang akan dipakai.

\section{KESIMPULAN}

Dari peneliti terdahulu terdapat implikasi bahwa Rasio Return On Asset (ROA), Return On Equity (ROE), dan Net Interest Margin (NIM) diduga memiliki pengaruh, baik secara simultan maupun secara parsial terhadap harga saham Bank yang terdaftar di BEI. Setelah penulis menguji kembali dugaan hipotesis hasil peneliti terdahulu, memang benar masih ada korelasi antara hipotesis peneliti terdahulu dengan hipotesis yang penulis teliti. yaitu hipotesisnya sebagai berikut:

Residual daripada Rasio Return On Asset (ROA), Return On Equity (ROE), dan Net Interest Margin (NIM) ternyata terdistribusi normal, sehingga asumsi klasik tentang kenormalan di model fixed effects terpenuhi.

Hipotesis yang pertama diusulkan telah menyatakan perkiraan Rasio Return On Asset (ROA), Return On Equity (ROE), dan Net Interest Margin (NIM) ternyata ada pengaruh yang simultan terhadap return saham pada bank yang terdaftar dan tercatat di PT Bursa Efek Indonesia. Diperoleh uji statistiknya nilai Signifikansinya $0,010<$ dari a $=0,05$.

Hipotesis yang kedua diusulkan dinyatakan perkiraan Rasio Return On Asset (ROA), Return On Equity (ROE), dan Net Interest Margin (NIM) ternyata ada pengaruh yang parsial terhadap return saham pada bank yang terdaftar dan tercatat di PT Bursa Efek Indonesia. Variable Rasio Return On Asset (ROA), Return On Equity (ROE) ternyata diterima dan hasil uji statistiknya diperoleh nilai signifikansinya $<$ dari a $=0,05$ sedangkan untuk Net Interest Margin (NIM) ternyata hasil uji statistic signifikansinya $>$ dari a $=0,05$ sehingga tidak dapat terbukti pengujiannya.

Nilai P-Value menunjukkan hasil yaitu sebesar 0,2960 yang mana nilai tersebut lebih 
dari 0,05. Sehingga Tes Lagrange Multiplier ini memperlihatkan bahwa menolak H1 yang mana metode estimasi terbaik adalah Random Effect Model. Dan jika P Value lebih besar dari pada 0,05 maka menerima H0 yang berarti metode estimasi yang terbaik adalah Common Effect Model.

\section{DAFTAR PUSTAKA}

Aldi, M., Nugraha, H., \& Saryadi, S. (2015). Pengaruh Car, Nim, Bopo, Dan Ldr Terhadap Tingkat Profitabilitas (Pada Bank Umum Go Public Periode 2008-2012. Jurnal Ilmu Administrasi Bisnis S1 Undip, 4(3), 157-166.

Asri, M. (2017). Analisis Rasio Dengan Variabel Eps (Earning Per Share), Roa (Return on Assets), Roe (Return on Equity), Bopo (Biaya Operasional Pendapatan Operasional) Terhadap Harga Saham Perusahaan Perbankan. Jurnal Ilmiah Ekonomi Bisnis, 22(3), 228998.

Chairatanawan, Y. (2008). Predictive Power of Financial Ratios to Stock Return in Thailand. Institute of International Studies, Ramkhamhaeng University Bangkok, Thailand, 2(2), 113-120.

Dempsey, M. (2017). Financial Leverage. Stock Markets and Corporate Finance, 225-255. https://doi.org/10.1142/9781786343277_0008

Faculty, M. S. (2016). Fisheries and Marine Science Faculty, Brawijaya University Received: May 26, 2016 /Accepted: November 11, 2016. 04(01), 28-35.

Jogiyanto Hartono. (2003). No Title. Teori Portofolio Dan Analisis Investasi.

Johar, A. (2017). Pengaruh Economic Value Added (Eva), Net Profit Margin (Npm), Return On Equity (Roe), Dan Return On Investment (Roi) Terhadap Harga Saham (Studi Pada Perusahaan Jasa Sektor Infrastruktur, Utilitas, dan Transportasi yang Terdaftar di BEI Tahun 2013-2015). Jurnal Administrasi Bisnis S1 Universitas Brawijaya, 46(1), 140146.

Nyoman, N., Ariasih, P., \& Utama, I. M. S. (2010). Pengaruh Jumlah Penduduk Dan Pdrb Per Kapita Kemandirian Keuangan Daerah Provinsi Bali. 543-562.

Parenrengi, S., \& Hendratni, T. W. (2018). Pengaruh dana pihak ketiga, kecukupan modal dan penyaluran kredit terhadap profitabilitas bank. Jurnal Manajemen Strategi Dan Aplikasi Bisnis, 1(1), 9-18. https://doi.org/10.36407/jmsab.v1i1.15

Rosada, N. (2003). Kinerja Keuangan Pada Bank Umum Syariah.

Saputri, R. I. (2018). Analisis Pengaruh CAR, NIM, BOPO dan LDR Terhadap Return Saham Pada Perusahaan Perbankan Yang Terdaftar Di Bursa Efek Indonesia 2015. Jurnal Ekobis Dewantara, 1(1), 149-158. https://doi.org/10.1017/CBO9781107415324.004

Sartono. (2012). No Title. ROE, 124.

Suad, H. (2018). | 45 pasar modal syariah dan konvensional. 3, 45-56. 
Syariah, K. D. A. N. (n.d.). Kompetisi net interest margin (nim) perbankan indonesia: bank konvensional dan syariah. 143-162.

Taswan, M. (2016). Pengaruh Cost Inefficiency, Capitalization, Diversification, Size , Dan, Profitability Terhadap Loan Quality. 761-768. 